\title{
Mechanism Study of Xanthate Adsorption on Sphalerite/Marmatite Surfaces by ToF-SIMS Analysis and Flotation
}

\author{
Hao Lai ${ }^{1,2}$, Jiushuai Deng ${ }^{1,3, *}{ }^{\mathbb{C}}$, Guixia Fan ${ }^{1}$, Hongxiang $X u^{3}{ }^{\circledR}$, Wenxiang Chen ${ }^{4}$, \\ Shimei $\mathrm{Li}^{2, *}$ and Lingyun Huang ${ }^{2}$ \\ 1 School of Chemical Engineering and Energy, Zhengzhou University, Zhengzhou 450001, China; \\ kjlaihao@163.com (H.L.); zdhgfgx@zzu.edu.cn (G.F.) \\ 2 State Key Laboratory of Complex Nonferrous Metal Resources Clean Utilization, \\ Faculty of Land Resource Engineering, Kunming University of Science and Technology, \\ Kunming 650093, China; hly@kmust.edu.cn \\ 3 School of Chemical \& Environmental Engineering, China University of Mining and Technology (Beijing), \\ Beijing 100083, China; xuhongxiang001@cumtb.edu.cn \\ 4 Guizhou Center Laboratory of Geological and Mineral Resources, Guiyang 550004, China; earst@163.com \\ * Correspondence: dengshuai689@163.com (J.D.); shimeikm@163.com (S.L.)
}

Received: 12 February 2019; Accepted: 22 March 2019; Published: 29 March 2019

\begin{abstract}
In this work, the active sites and species involved in xanthate adsorption on sphalerite/marmatite surfaces were studied using adsorption capacity measurements, single mineral flotation, and time-of-flight secondary ion mass spectrometry (ToF-SIMS) analysis. The effects of Fe concentration on the xanthate adsorption capacity, $\mathrm{Cu}$ activation, and the flotation response of sphalerite/marmatite were determined. A discovery was that xanthate can interact with Fe atoms in the crystal of sphalerite/marmatite, as well as with $\mathrm{Zn}$ and $\mathrm{Cu}$ on the surface. We detected $\mathrm{C}_{2} \mathrm{~S}_{2}{ }^{-}$fragment ions from dixanthogen, and dixanthogen may have been adsorbed on the surface of marmatite. The amounts of $\mathrm{Cu}$ and copper xanthate adsorbed on the marmatite surface were lower than those on the sphalerite surface, because Fe occupies $\mathrm{Cu}$ and $\mathrm{Zn}$ exchange sites. These results help to address the long-standing controversy regarding the products and mechanisms of xanthate adsorption on Fe-bearing sphalerite surfaces.
\end{abstract}

Keywords: sphalerite; marmatite; ToF-SIMS; xanthate; impurity; species

\section{Introduction}

Sphalerite is an important $\mathrm{Zn}$-containing mineral and is often found in association with sulfide minerals such as galena, pyrite, and chalcopyrite [1,2]. In industry, the flotation method is generally used to achieve the separation of these different minerals [3,4]. During separation of sphalerite and pyrite, copper sulfate is added to activate the sphalerite, and then xanthate is added to make the sphalerite surface hydrophobic and induce floating $[5,6]$. Copper sulfate and xanthate are used in the recovery of single zinc sulfide ores because they enable substantial recovery of sphalerite.

Xanthate adsorption on sphalerite depends on the nature of the flotation pulp, e.g., the pulp $\mathrm{pH}$, the ionic composition of the flotation water, and release of the components of fluid inclusions [7-10]. The adsorption process also depends on the properties of the sphalerite crystals, e.g., crystal lattice defects, and doping and substitution by impurity atoms [7,11-13]. Sphalerite usually contains significant amounts of $\mathrm{Cd}$ and $\mathrm{Mn}$ substituted for $\mathrm{Zn}$, and small amounts of other elements, e.g., $\mathrm{Ga}, \mathrm{Ge}, \mathrm{In}, \mathrm{Co}$, and $\mathrm{Hg}$ [14]. The most common impurity is Fe, which is generally present at levels up to $26 \mathrm{~mol} \%$, although contents of $56 \mathrm{~mol} \%$ have been reported [15-17]. 
Fe-bearing sphalerite, known as marmatite, is usually formed by isomorphous doping, substitution, or solid dissolution of Fe atoms in sphalerite crystals during mineralization and crystallization. Marmatite is one of the most important zinc sulfide minerals, and is globally distributed, e.g., in Australia, the United States, China, and Kazakhstan [18-20]. Infrared spectroscopy, ultraviolet (UV) spectroscopy, X-ray absorption spectroscopy, and density functional theory calculations have been used to study the effects of Fe on xanthate adsorption on sphalerite/marmatite $[13,19,21-26]$. Chen et al. [21] used density functional theory calculations to simulate the effects of Fe impurities on the electronic structure of sphalerite. The results showed that Fe impurities changed the sphalerite from a p-type to an n-type semiconductor. This facilitates oxidation of xanthate on the sphalerite surface to dixanthogen. Szczypa et al. [22] synthesized artificial sphalerite samples with various Fe contents and compared the concentrations of residual xanthate in the solutions after xanthate adsorption by marmatite. Their results showed that the amount of xanthate that remained in the solution decreased with increasing amount of Fe. The thickness of the xanthate layer on the sphalerite surface was found to be less than one molecule layer. At $\mathrm{pH}$ 6-10, the amount of xanthate adsorption was not affected by the solution $\mathrm{pH}$. Boulton [23] found that at $\mathrm{pH} 11$ the amount of xanthate adsorbed by sphalerite was twice that adsorbed by marmatite after $\mathrm{Cu}$ activation. Gigowski et al. [24] suggested that xanthate adsorption at $\mathrm{pH} 6.5$ strongly depends on activation by $\mathrm{Cu}$, regardless of the Fe content. In terms of the effects of $\mathrm{Fe}$ on $\mathrm{Cu}$ activation of sphalerite, Chandra et al. [25] reported that Fe impurities decrease the adsorption of $\mathrm{Cu}$ ions on the sphalerite surface. Boulton et al. suggested that Fe decreases the exchange of $\mathrm{Cu}$ ions and $\mathrm{Zn}$ [26]. However, the study by Harmer et al. [19] showed that surface adsorption of $\mathrm{Cu}$ increased with increasing Fe addition. The number of surface defects in marmatite is greater than that in sphalerite with a low Fe content, therefore more $\mathrm{Cu}$ ions can be adsorbed on the surface. These results suggest that Fe has significant effects on $\mathrm{Cu}$ activation of sphalerite as well as xanthate adsorption, but this is still debatable.

As is well-known, xanthate can increase the floatability of Fe-bearing sphalerites but various adsorption products are formed on the sphalerite. The following questions still need to be satisfactorily answered. What are the main adsorption products formed from xanthate in Fe-bearing sphalerite? What are the active sites? What are the effects of Fe impurities and $\mathrm{Cu}$ ions on the adsorption of xanthate in Fe-bearing sphalerite? The results of previous studies are controversial. Some researchers have suggested that the xanthate products adsorbed on the surface of non-activated sphalerite are zinc xanthate and dixanthogen $[27,28]$. Some studies have shown that xanthate is adsorbed as copper xanthate after $\mathrm{Cu}$ activation [29-31]. However, X-ray photoelectron spectroscopy results obtained by Mikhlin et al. [32] showed that almost no zinc xanthate or dixanthogen was present. Gigowski et al. [24] found that xanthate was preferentially adsorbed on marmatite.

In this study, to explain the contradictory results of previous studies of xanthate adsorption products and their formation mechanisms in sphalerite/marmatite, we used adsorption determination, single mineral flotation, and time-of-flight secondary ion mass spectrometry (ToF-SIMS) to investigate the effects of iron on xanthate adsorption and identify their active sites.

\section{Materials and Methods}

\subsection{Materials}

Natural sphalerite samples were obtained from a polymetallic ore deposit in Dulong, Yunnan Province, China. Marmatite samples were obtained from a polymetallic mining area in Nandan, Guangxi Province, China. The samples were manually crushed and handpicked, dry ground in an agate mortar, and dry screened to obtain particles of size $37-74 \mu \mathrm{m}$ for flotation and xanthate adsorption capacity tests. Chemical assays showed that the sphalerite (SPH1) contained $63.73 \mathrm{wt} \%$ $\mathrm{Zn}, 0.60 \mathrm{wt} \% \mathrm{Fe}, 31.80 \mathrm{wt} \% \mathrm{~S}, 1.16 \mathrm{wt} \% \mathrm{~Pb}$, and $0.15 \mathrm{wt} \% \mathrm{Cu}$, and the marmatite (SPH5) contained $48.26 \mathrm{wt} \% \mathrm{Zn}, 14.70 \mathrm{wt} \% \mathrm{Fe}, 33.10 \mathrm{wt} \% \mathrm{~S}, 0.09 \mathrm{wt} \% \mathrm{~Pb}$, and $0.17 \mathrm{wt} \% \mathrm{Cu}$. The results of the above chemical analysis indicated that the purity of sphalerite and marmatite were both high and could 
be used as suitable research objects. Analytically pure $\mathrm{CuSO}_{4} \cdot 5 \mathrm{H}_{2} \mathrm{O}$ was purchased from the Tianjin Chemical Reagent Factory (Tianjin, China), sodium butyl xanthate and terpineol were purchased from Zhuzhou Flotation Reagents Ltd. (Zhuzhou, China). Deionized water was used in all experiments.

\subsection{Adsorption Capacity Measurements}

The concentration of xanthate was determined by UV spectroscopy (UV765, Jingke, Shanghai, China). Before the xanthate adsorption capacity tests, the characteristic absorption wavelength of sodium butyl xanthate was determined; the wavelength was $301 \mathrm{~nm}$. The absorption wavelength was used to establish an equation for the relationship between xanthate concentration and solution absorbance. A sample ( $2 \mathrm{~g}$ ) of particle size $37-74 \mu \mathrm{m}$ was weighed with electronic scales. Before adding the reagent, the sample was ultrasonically cleaned in deionized water three times ( $3 \mathrm{~min}$ for each time) to remove surface oxidizing materials. For the xanthate adsorption capacity test without $\mathrm{Cu}$ activation, sodium butyl xanthate solution $(40 \mathrm{~mL})$ was injected into a $100 \mathrm{~mL}$ beaker containing the sample. The beaker was placed on a thermostatic magnetic stirrer rotating at a speed of $1000 \mathrm{rpm}$. Agitation was stopped after $3 \mathrm{~min}$, the slurry was centrifuged, and the concentration of sodium butyl xanthate in the separated liquid was determined by UV spectroscopy by using the relationship between the xanthate concentration and solution absorbance. The xanthate adsorption capacity was calculated as

$$
\Gamma=\frac{\left(C_{0}-C\right) \times V}{m}
$$

where $\Gamma$ is the amount of sodium butyl xanthate adsorbed (mol/g); $C_{0}$ is the initial concentration of sodium butyl xanthate $(\mathrm{mol} / \mathrm{L}) ; C$ is the concentration of sodium butyl xanthate in the solution after adsorption of butyl xanthate on the sample ( $\mathrm{mol} / \mathrm{L})$, i.e., the concentration in the separation liquid; $V$ is the solution volume (L); and $m$ is the sample mass (g).

For the xanthate adsorption test with $\mathrm{Cu}$ activation, $\mathrm{CuSO}_{4}$ solution $(40 \mathrm{~mL})$ of concentration $1 \times 10^{-5} \mathrm{~mol} / \mathrm{L}$ was injected into a $100 \mathrm{~mL}$ beaker containing the sample $(2 \mathrm{~g})$. The beaker was placed on a thermostatic magnetic stirrer rotating at a speed of $1000 \mathrm{rpm}$. Agitation was stopped after $2 \mathrm{~min}$. The pulp was centrifuged to obtain a Cu-activated sample for the xanthate adsorption capacity test. The subsequent steps in the xanthate adsorption test were the same as those in the test without $\mathrm{Cu}$ activation. All xanthate adsorption tests were performed at natural $\mathrm{pH}$.

\subsection{Single Mineral Flotation}

Single mineral flotation was used for flotation tests on sphalerite and marmatite. For the flotation test without $\mathrm{Cu}$ activation, a sample $(2 \mathrm{~g})$ of particle size $37-74 \mu \mathrm{m}$ was weighed with electronic scales and the sample surface was cleaned ultrasonically to remove surface oxidizing materials before flotation. The rinsed sample was poured into a $50 \mathrm{~mL}$ flotation cell containing deionized water $(40 \mathrm{~mL})$. The flotation machine, which had a rotor speed of $1600 \mathrm{rpm}$, was started and then sodium butyl xanthate solution $\left(1 \times 10^{-4} \mathrm{~mol} / \mathrm{L}\right)$ and $2 \#$ oil $(20 \mathrm{mg} / \mathrm{L})$ were added. Froths were collected for $220 \mathrm{~s}$ by turning on the air valve at a rate of $35 \mathrm{~mL} / \mathrm{min}$ before stopping flotation. The collected flotation sphalerite and the Fe-doped sphalerite left at the bottom of the flotation tank were filtered and dried and the flotation recovery of the Fe-doped sphalerite was calculated. For the flotation test after $\mathrm{Cu}$ activation, $\mathrm{CuSO}_{4}$ solution $\left(1 \times 10^{-5} \mathrm{~mol} / \mathrm{L}\right)$ was first added to the pulp; the other steps were the same as those in the test without $\mathrm{Cu}$ activation. All flotation tests were performed at natural $\mathrm{pH}$.

\subsection{ToF-SIMS Analysis}

The preparation of bulk Sphalerite/marmatite samples follows the following steps: (1) The samples were cut into rectangular shaped pieces approximately $1.5 \times 1 \times 0.5 \mathrm{~cm}$ in length, width, and depth, using a fine slow diamond saw. (2) Cut samples were polished with wet silicon carbide paper in the sequence of $600,800,1200,2000$, and 4000 meshes, and then polished with 5 and $1 \mu \mathrm{m}$ alumina powder suspensions, respectively. (3) The freshly polished samples were ultrasonically 
cleaned for $3 \mathrm{~min}$ each in deionized water, absolute ethanol, and deionized water. (4) The cleaned samples were dried by using high-purity nitrogen. The samples that were not activated by $\mathrm{Cu}$ were placed in a sodium butyl xanthate solution $(40 \mathrm{~mL})$ of concentration $1 \times 10^{-4} \mathrm{~mol} / \mathrm{L}$ for $15 \mathrm{~min}$ and then removed. The samples were dried with high-purity nitrogen. The samples activated by $\mathrm{Cu}$ were first placed in $\mathrm{CuSO}_{4}$ solution $(40 \mathrm{~mL})$ of concentration $1 \times 10^{-4} \mathrm{~mol} / \mathrm{L}$, and reacted for $15 \mathrm{~min}$, and then removed and immediately placed in sodium butyl xanthate solution $(40 \mathrm{~mL})$ of concentration $1 \times 10^{-4} \mathrm{~mol} / \mathrm{L}$. After reaction for $15 \mathrm{~min}$, they were removed and dried with high-purity nitrogen. The dried samples were immediately placed in the ToF-SIMS V (ION-TOF GmbH, Münster, Germany) sample chamber. The analysis was started when the vacuum in the sample chamber reached $1 \times 10^{-9}$ mbar. A $30 \mathrm{keV} \mathrm{Bi}_{3}{ }^{+}$primary gun with a pulsed current of $1.04 \mathrm{pA}$ was used to analyze a sample area of $500 \times 500 \mu \mathrm{m}$, and a flood gun was used for charge compensation. $\mathrm{The} \mathrm{Bi}_{3}{ }^{+}$beam was rastered in random mode, $256 \times 256$ pixels, and was stopped after $240 \mathrm{~s}$. Positive-ion and negative-ion spectra were recorded with the instrument optimized for high mass resolution $(m / \Delta m \sim 6000-9000$ at $m / z$ 64) over the mass range $m / z$ 0-815. ToF-SIMS spectra were collected in four different areas of each sample surface. Positive-ion spectra were calibrated against the peaks for $\mathrm{C}^{+}, \mathrm{CH}_{3}{ }^{+}, \mathrm{C}_{2} \mathrm{H}_{3}{ }^{+}$, and $\mathrm{Zn}^{+}$before further analysis. Negative-ion spectra were calibrated against the peaks for $\mathrm{C}^{-}, \mathrm{CH}^{-}, \mathrm{C}_{2}^{-}, \mathrm{C}_{2} \mathrm{H}^{-}$, and $\mathrm{S}^{-}$before further analysis. Data acquisition and subsequent data processing and analysis were performed using ION-TOF SurfaceLab software (6.7, ION-TOF GmbH, Münster, Germany).

\section{Results}

\subsection{Effects of Fe Concentration on Xanthate Adsorption and Flotation Response}

In this work, UV spectroscopy was used to determine the adsorption capacity of butyl xanthate (BX) on sphalerite and marmatite with $\mathrm{Fe}$ contents of $0.6 \%$ and $14.7 \%$, respectively (Figure 1). The results show that at $\mathrm{pH} 6.5$ without copper sulfate addition, the quantity of xanthate adsorbed on sphalerite was five times that for marmatite. After $\mathrm{Cu}$ activation, the adsorption capacities for xanthate on the sphalerite/marmatite surface increased. At this point, the amount of xanthate adsorbed on sphalerite was 2.5 times that adsorbed on marmatite.

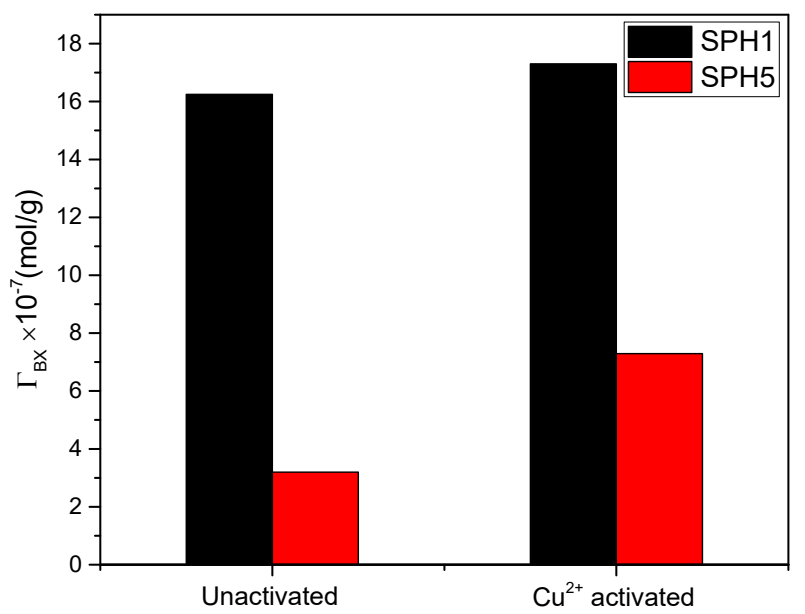

Figure 1. Butyl xanthate (BX) adsorption capacity of sphalerite/marmatite at $\mathrm{pH} 6.5$; concentrations of $\mathrm{Cu}^{2+}$ and $\mathrm{BX}$ were $1 \times 10^{-5}$ and $1 \times 10^{-4} \mathrm{~mol} / \mathrm{L}$, respectively; the black histogram is for sphalerite (SPH1) and the red histogram is for marmatite (SPH5).

The xanthate adsorption capacity of sphalerite only increased by $1 \times 10^{-7} \mathrm{~mol} / \mathrm{g}$ after $\mathrm{Cu}$ activation; the adsorption capacity increased by $4 \times 10^{-7} \mathrm{~mol} / \mathrm{g}$ for marmatite after $\mathrm{Cu}$ activation. This indicates that $\mathrm{Cu}$ activation has a greater effect on the xanthate adsorption capacity of marmatite than on that of sphalerite. Although the xanthate adsorption capacity on the marmatite increased 
after $\mathrm{Cu}$ activation, it was still much lower than that for sphalerite. These results are consistent with those reported by Boulton [23]: Fe impurities in the crystal lattice of sphalerite are not conducive to xanthate adsorption.

Figure 2 shows the flotation responses of sphalerite/marmatite. The floatability of sphalerite was better than that of marmatite. In the absence of xanthate flotation, the flotation recovery of marmatite was only $51.15 \%$, whereas that of sphalerite was $78.43 \%$. After xanthate addition, the flotation recovery of marmatite increased to $69.1 \%$, and that for the sphalerite was $84.1 \%$.

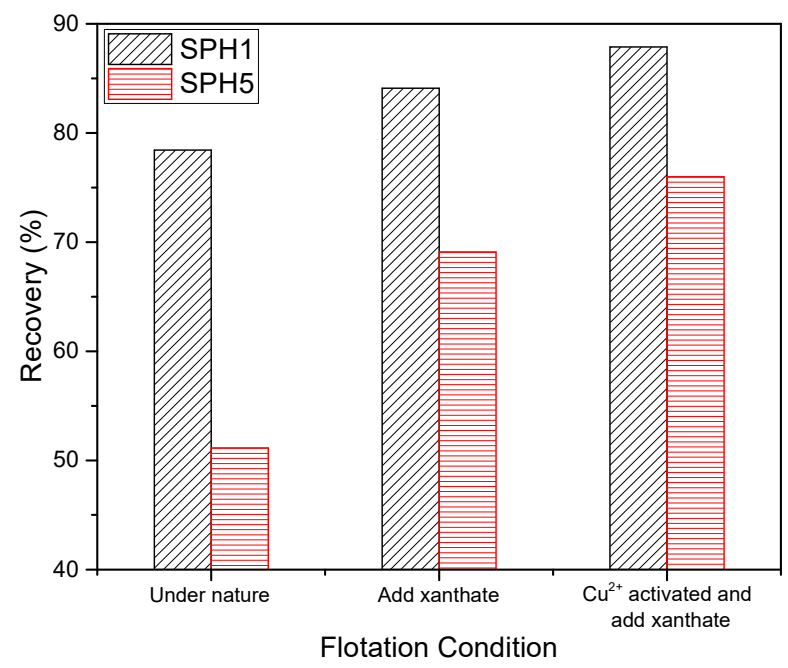

Figure 2. Flotation recovery of sphalerite/marmatite at pH 6.5 in $220 \mathrm{~s}$; concentrations of $\mathrm{Cu}^{2+}$ and BX are $1 \times 10^{-5}$ and $1 \times 10^{-4} \mathrm{~mol} / \mathrm{L}$, respectively; the black histogram is for sphalerite (SPH1) and the red histogram is for marmatite (SPH5).

The flotation recovery of marmatite increased after $\mathrm{CuSO}_{4}$ addition. This clearly indicates that $\mathrm{Cu}$ ions activate marmatite in a xanthate flotation system. The studies by Popov et al. [33] and Boulton [23] showed that the flotation recoveries of marmatite were low under alkaline and non-collector conditions. Xanthate can improve the floatability of marmatite, and $\mathrm{Cu}$ activation can promote marmatite flotation in a xanthate system. The results in Figure 1 indicate that Fe impurities in marmatite are not conducive to xanthate adsorption or marmatite flotation.

\subsection{ToF-SIMS Spectra Analysis}

In ToF-SIMS analysis, a small number of primary ions $\left(<10^{13} \mathrm{~cm}^{-2}\right)$ are injected into the material surface. The ToF-SIMS mass spectra are obtained by collecting secondary ions from 1-2 $\mathrm{nm}$ of materials surface. Its detection limit is at the ppm-ppb level [34]. Mass spectrometry can provide structural information and two-dimensional and three-dimensional distribution information for materials. In this study, a pulsed $30 \mathrm{keV} \mathrm{Bi}_{3}{ }^{+}$primary ion beam was used to collect mass spectra of the sphalerite/marmatite samples surface, to identify the active sites for xanthate on sphalerite/marmatite.

Figure 3a-e shows the positive-ion mass spectra in the mass range 112-157 m/z of marmatite. Xanthate addition led to the formation of $\mathrm{CSFe}^{+}$and $\mathrm{CSZn}^{+}$fragment ions on the marmatite surface. The $\mathrm{Cu}$-activated marmatite surface was enriched with fragment ions such as $\mathrm{CSFe}^{+}, \mathrm{CSCu}^{+}, \mathrm{CSZn}^{+}$, $\mathrm{CS}^{65} \mathrm{Cu}^{+}, \mathrm{Cu}_{2} \mathrm{~S}^{+}, \mathrm{Cu}_{2} \mathrm{HS}^{+}, \mathrm{ZnCuH}_{2} \mathrm{~S}^{+}$, and $\mathrm{Cu}_{3} \mathrm{~S}^{+}$after xanthate absorption.

Figure $3 \mathbf{f}-\mathbf{n}$ shows the negative-ion mass spectra in the mass range $112-157 \mathrm{~m} / \mathrm{z}$ of marmatite. The results show that xanthate addition led to the marmatite surface enriched with $\mathrm{OCSFe}^{-}, \mathrm{OCSZn}^{-}$, $\mathrm{OCS}_{2} \mathrm{Fe}^{-}, \mathrm{C}_{4} \mathrm{H}_{9} \mathrm{OCS}_{2}{ }^{-}$, and $\mathrm{OCS}_{2} \mathrm{Zn}^{-}$fragment ions. The $\mathrm{Cu}$-activated marmatite surface was enriched with $\mathrm{OCSFe}^{-}, \mathrm{OCSCu}^{-}, \mathrm{OCSZn}^{-}, \mathrm{OCS}_{2} \mathrm{Fe}^{-}, \mathrm{OCS}_{2} \mathrm{Cu}^{-}, \mathrm{C}_{4} \mathrm{H}_{9} \mathrm{OCS}_{2}{ }^{-}$, and $\mathrm{OCS}_{2} \mathrm{Zn}^{-}$ fragment ions after xanthate adsorption. 

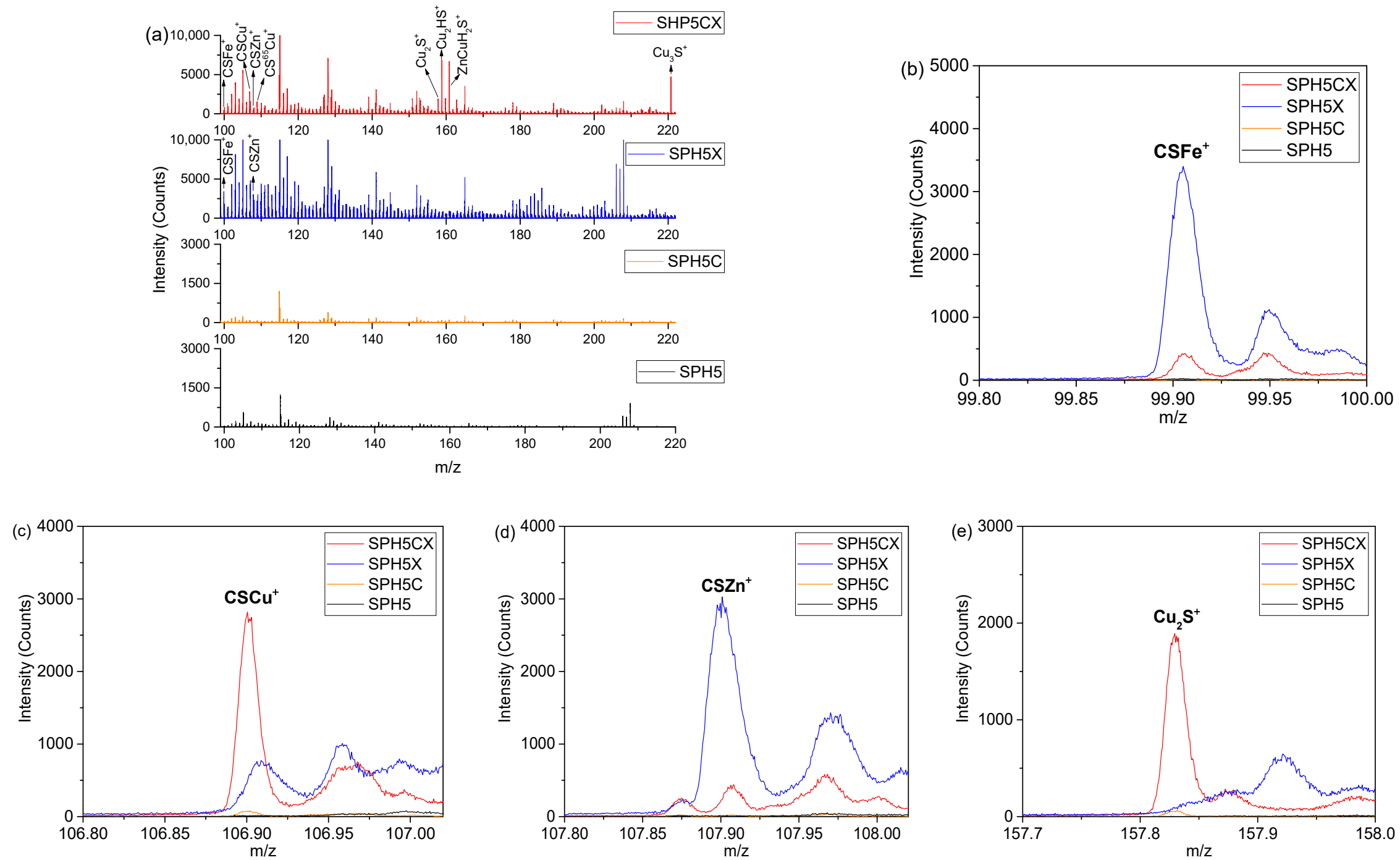

Figure 3. Cont. 

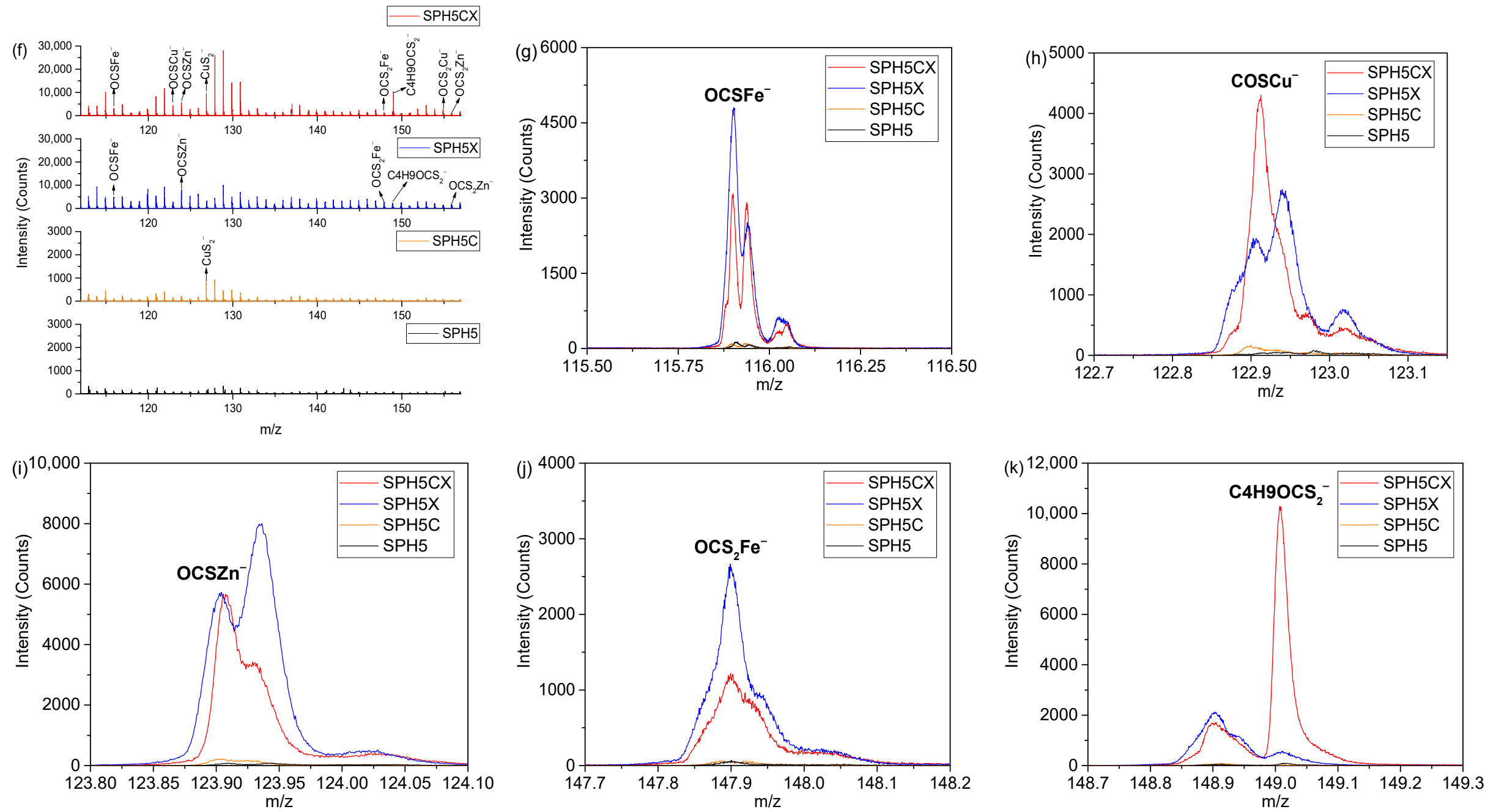

Figure 3. Cont. 

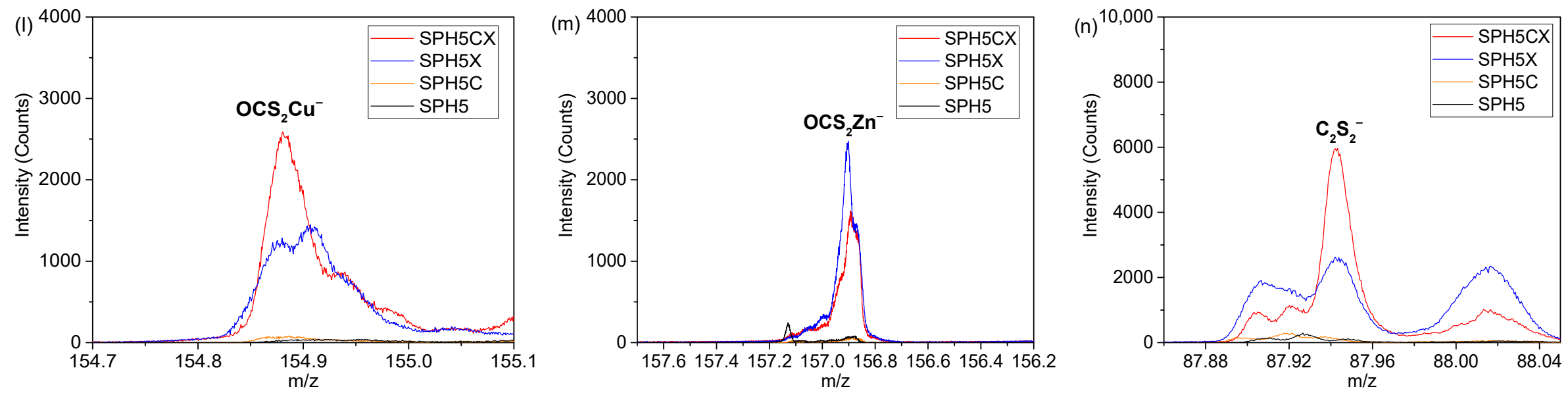

Figure 3. Time-of-flight secondary ion mass spectrometry (ToF-SIMS) spectra of marmatite (SPH5) at pH 6.5: (a-e) positive-ion mass spectra and (f-n) negative-ion mass spectra. The red line is the mass spectra of $\mathrm{Cu}$-activated marmatite surface after $\mathrm{BX}$ absorption; the blue line is the mass spectra of $\mathrm{BX}$ absorbed marmatite surface; and the orange line is the mass spectra of the Cu-activated marmatite surface; the black line is the mass spectra of marmatite surface. 
Figure 3a-n shows that xanthate can be adsorbed on marmatite surface with or without $\mathrm{Cu}$ activation. It can interact with $\mathrm{Zn}, \mathrm{Fe}$, and $\mathrm{Cu}$ to form the corresponding metal xanthates. We also detected products similar to those observed for marmatite in the ToF-SIMS mass spectra of the sphalerite. Previous studies have clarified the role of xanthate interactions with $\mathrm{Zn}$ and $\mathrm{Cu}$, and Figure $3 a-n$ confirms these previous observations. The results of this work show that xanthate interacts with $\mathrm{Fe}$ in the crystal of marmatite.

Marmatite surface has higher intensity of fragment ion peaks from iron xanthate $\left(\mathrm{CSFe}^{+}, \mathrm{OCSFe}^{-}\right.$, and $\left.\mathrm{OCS}_{2} \mathrm{Fe}^{-}\right)$and zinc xanthate $\left(\mathrm{CSZn}^{+}, \mathrm{OCSZn}^{-}\right.$, and $\left.\mathrm{OCS}_{2} \mathrm{Zn}^{-}\right)$than Cu-activated marmatite surface after xanthate absorption. However, $\mathrm{Cu}$-activated marmatite surface has higher intensity of fragment ion peaks from xanthate $\left(\mathrm{C}_{4} \mathrm{H}_{9}{ }^{+}, \mathrm{C}_{4} \mathrm{H}_{9} \mathrm{O}^{-}\right.$, and $\left.\mathrm{C}_{4} \mathrm{H}_{9} \mathrm{OCS}_{2}{ }^{-}\right)$than marmatite surface after xanthate absorption. In addition, the fragment ion peaks from copper xanthate $\left(\mathrm{CSCu}^{+}, \mathrm{OCSCu}^{+}\right.$, and $\mathrm{OCS}_{2} \mathrm{Cu}^{+}$) were detected on the $\mathrm{Cu}$-activated marmatite surface after xanthate absorption. This is in agreement with the experimental result that the xanthate adsorption capacity of the $\mathrm{Cu}$-activated marmatite surface was greater than that of the marmatite surface (Figure 1).

These results show that for $\mathrm{Cu}$-activated marmatite, xanthate preferentially interacts with surface $\mathrm{Cu}$, and the interactions are stronger than those with Fe in the crystal. We also detected the $\mathrm{C}_{2} \mathrm{~S}_{2}{ }^{-}$from dixanthogen. Dixanthogen adsorption on the marmatite surface is therefore possible.

After xanthate adsorption on the Cu-activated marmatite, fragment ions $\left(\mathrm{Cu}_{2} \mathrm{~S}^{+}, \mathrm{Cu}_{2} \mathrm{HS}^{+}\right.$, $\mathrm{ZnCuH}_{2} \mathrm{~S}^{+}, \mathrm{Cu}_{3} \mathrm{~S}^{+}$, and $\mathrm{CuS}_{2}{ }^{-}$) from $\mathrm{Cu}-\mathrm{S}$ compounds were detected. The intensities of these fragment ions were much weaker than those of fragment ions from $\mathrm{Cu}$-activated marmatite without xanthate addition. This is probably because these $\mathrm{Cu}-\mathrm{S}$ fragment ions originated from different $\mathrm{Cu}-\mathrm{S}$ compounds, or $\mathrm{Cu}-\mathrm{S}$ compounds were covered by xanthate. In addition, the ToF-SIMS matrix may affect the strengths of these fragment ions.

Figure 4 shows semi-quantitative results for surface fragment ions for xanthate absorbed sphalerite/marmatite. The results show that the $\mathrm{Zn}^{+}, \mathrm{C}_{4} \mathrm{H}_{9}{ }^{+}, \mathrm{CSZn}^{+}, \mathrm{C}_{4} \mathrm{H}_{9} \mathrm{O}^{-}, \mathrm{C}_{4} \mathrm{H}_{9} \mathrm{OCS}_{2}{ }^{-}, \mathrm{OCSZn}^{-}$, and $\mathrm{OCS}_{2} \mathrm{Zn}^{-}$from the sphalerite after xanthate addition were stronger than those from the marmatite, i.e., $\mathrm{Fe}^{+}, \mathrm{OCSFe}^{-}$, and $\mathrm{OCS}_{2} \mathrm{Fe}^{-}$were weaker. This indicates that xanthate adsorption on the surface of sphalerite is higher than that on marmatite. This is consistent with the results shown in Figure 1. Iron xanthate adsorption is higher and zinc xanthate adsorption is lower because there is more Fe and less $\mathrm{Zn}$ on the surface of marmatite.
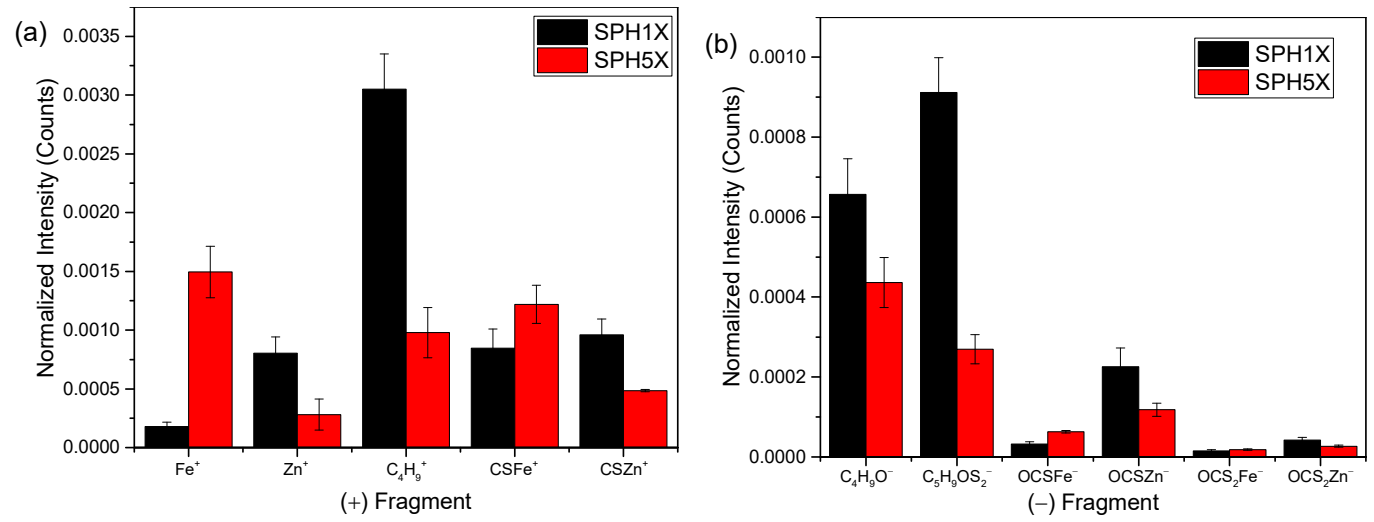

Figure 4. Normalized intensity of fragment ions for BX absorbed sphalerite (SPH1)/marmatite (SPH5): (a) positive fragment ions and (b) negative fragment ions; the black histogram is the BX absorbed sphalerite and the red histogram is the BX absorbed marmatite.

Figure 5 shows the semi-quantitative results for surface fragment ions from $\mathrm{Cu}$-activated sphalerite/marmatite after xanthate addition. The results show that the surface $\mathrm{Zn}^{+}, \mathrm{Cu}^{+}, \mathrm{C}_{4} \mathrm{H}_{9}{ }^{+}$, $\mathrm{CSCu}^{+}, \mathrm{CSZn}^{+}, \mathrm{C}_{4} \mathrm{H}_{9} \mathrm{O}^{-}, \mathrm{C}_{4} \mathrm{H}_{9} \mathrm{OCS}_{2}{ }^{-}, \mathrm{OCSCu}^{-}, \mathrm{OCSZn}^{-}, \mathrm{OCS}_{2} \mathrm{Cu}^{-}$, and $\mathrm{OCS}_{2} \mathrm{Zn}^{-}$ions from $\mathrm{Cu}$-activated sphalerite after xanthate addition were stronger than those from $\mathrm{Cu}$-activated marmatite; 
the $\mathrm{Fe}^{+}, \mathrm{OCSFe}^{-}$, and $\mathrm{OCS}_{2} \mathrm{Fe}^{-}$ions were weaker. This indicates that more xanthate was adsorbed on the surface of $\mathrm{Cu}$-activated sphalerite than on $\mathrm{Cu}$-activated marmatite. This is in agreement with the results shown in Figure 1.
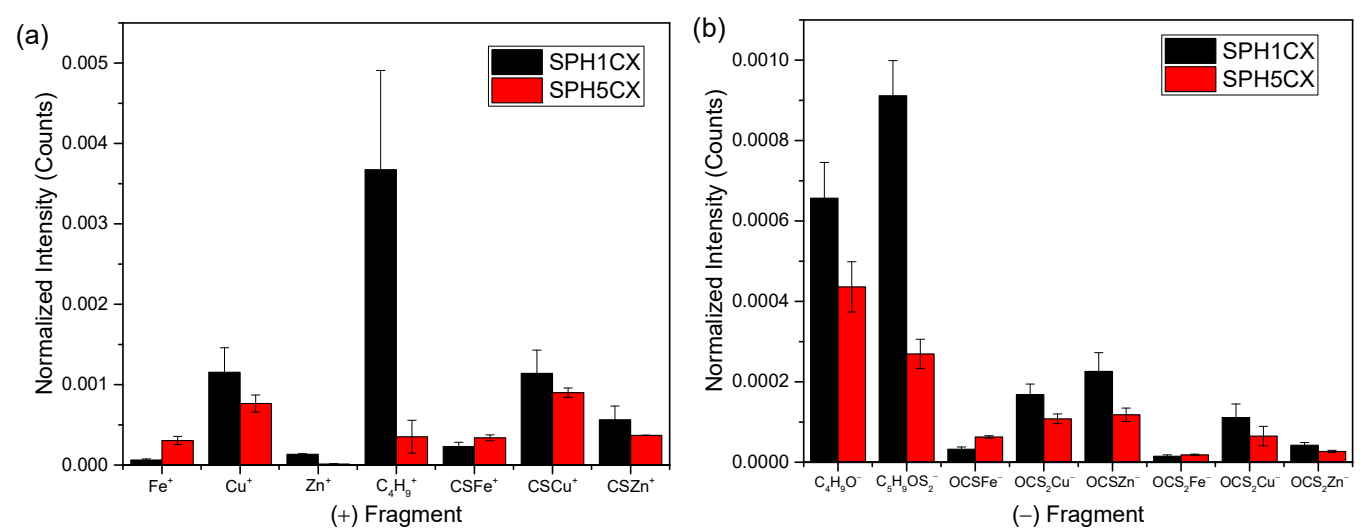

Figure 5. Normalized intensity of surface fragment ions in ToF-SIMS for Cu-activated sphalerite (SPH1)/marmatite (SPH5) after $\mathrm{BX}$ addition at $\mathrm{pH}$ 6.5: (a) positive fragment ions and (b) negative fragments ions; the black histogram is $\mathrm{Cu}$-activated sphalerite and the red histogram is Cu-activated marmatite.

We also detected $\mathrm{Zn}^{+}, \mathrm{CSZn}^{+}, \mathrm{OCSZn}^{-}$, and $\mathrm{OCS}_{2} \mathrm{Zn}^{-}$on the surfaces of Cu-activated sphalerite/marmatite. However, it is generally considered that $\mathrm{Cu}$ activation of a sphalerite surface involves $\mathrm{Cu}$ ions replacing $\mathrm{Zn}$ in the crystal lattice $[35,36]$. Therefore, $\mathrm{Cu}$ may not completely replace $\mathrm{Zn}$ in the sphalerite/marmatite surface layer $1-2 \mathrm{~nm}$.

The study by Gerson et al. [37] showed that after reaction of $\mathrm{Cu}$ and sphalerite for $15 \mathrm{~min}$, less than $40 \%$ of $\mathrm{Zn}$ was replaced by $\mathrm{Cu}$, even in the outermost layer of sphalerite. The $\mathrm{Cu}^{+}, \mathrm{OCSCu}^{-}$, and $\mathrm{OCS}_{2} \mathrm{Cu}^{-}$ions on the surface of $\mathrm{Cu}$-activated marmatite were weaker than those for $\mathrm{Cu}$-activated sphalerite. This indicates that smaller amounts of $\mathrm{Cu}$ and copper xanthate were adsorbed on the surface of marmatite.

Chen et al. [38] performed density functional theory calculations and reported that Fe on sphalerite favors the replacement of $\mathrm{Cu}$ with $\mathrm{Zn}$. The number of sites for exchange of $\mathrm{Cu}$ and $\mathrm{Zn}$ decreases because $\mathrm{Fe}$ on the sphalerite surface cannot be replaced by $\mathrm{Cu}$. It is therefore considered that $\mathrm{Cu}$ and copper xanthate adsorption are lower on the surface of marmatite because Fe occupies sites for exchange of $\mathrm{Cu}$ and $\mathrm{Zn}$.

The results in Figure 3 show that xanthate will interact with Fe on the surface of marmatite. Figures 4 and 5 show that the presence of Fe is not conducive to xanthate adsorption because Fe occupies $\mathrm{Cu}$ and $\mathrm{Zn}$ exchange sites. Figures 1 and 2 show that Fe is unfavorable for xanthate adsorption and sphalerite flotation. We can therefore infer that the interactions between xanthate and Fe are weaker than those between xanthate and $\mathrm{Zn}$ or $\mathrm{Cu}$. This makes xanthate adsorption on the marmatite surface more difficult.

\subsection{ToF-SIMS Imaging Analysis}

Figure 6 shows the ToF-SIMS negative-ion images of xanthate absorbed marmatite surface at $\mathrm{pH}$ 6.5. In the $500 \times 500 \mu \mathrm{m}^{2}$ analysis area, the fragment ion $\mathrm{C}_{4} \mathrm{H}_{9} \mathrm{OCS}_{2}{ }^{-}$from xanthate is bright (higher distribution) in some areas, and dark (lower distribution) in others. This indicates uneven xanthate adsorption on the unactivated marmatite. The image of the $\mathrm{OCS}_{2} \mathrm{Fe}^{-}$fragment ion from iron xanthate is similar to that of the $\mathrm{OCS}_{2} \mathrm{Zn}^{-}$fragment ion from zinc xanthate, and most areas are of the same brightness. This shows that zinc xanthate and iron xanthate have similar, uniform distributions, and xanthate is not adsorbed only in the form of metal xanthates. The distribution of $\mathrm{C}_{2} \mathrm{~S}_{2}{ }^{-}$from 
dixanthogen is different from that of $\mathrm{C}_{4} \mathrm{H}_{9} \mathrm{OCS}_{2}{ }^{-}$, which further confirmed that dixanthogen was adsorbed on the marmatite surface.

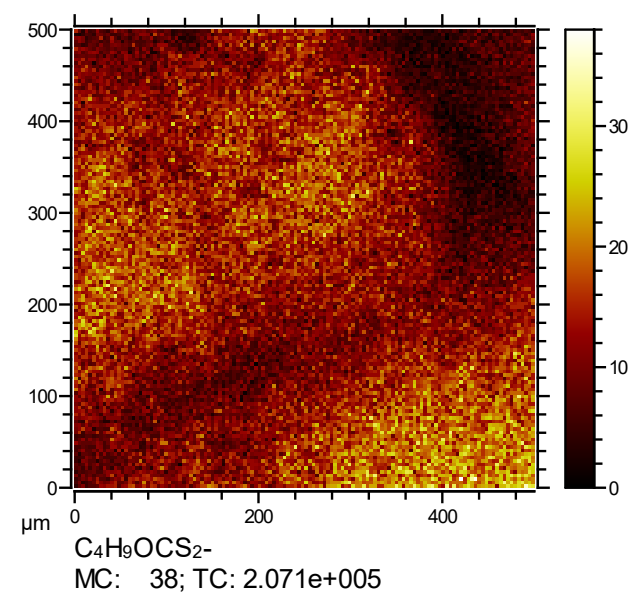

(a)

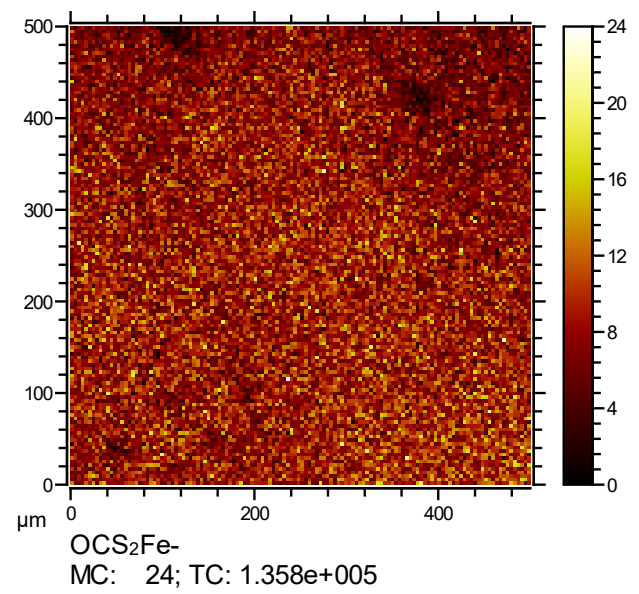

(c)

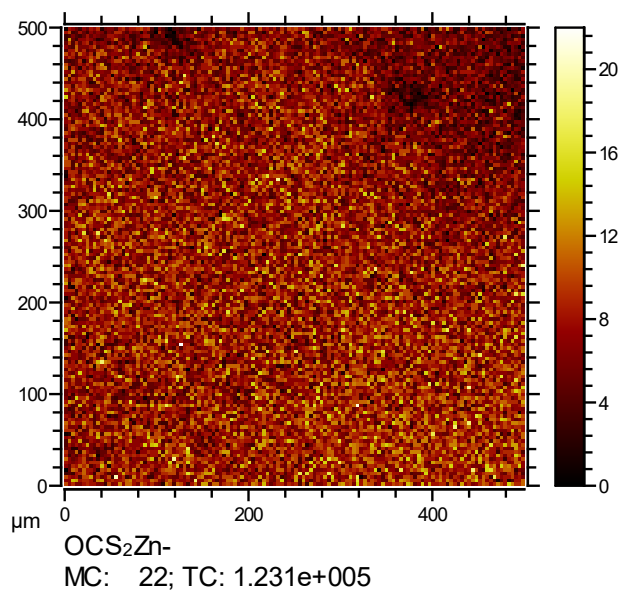

(b)

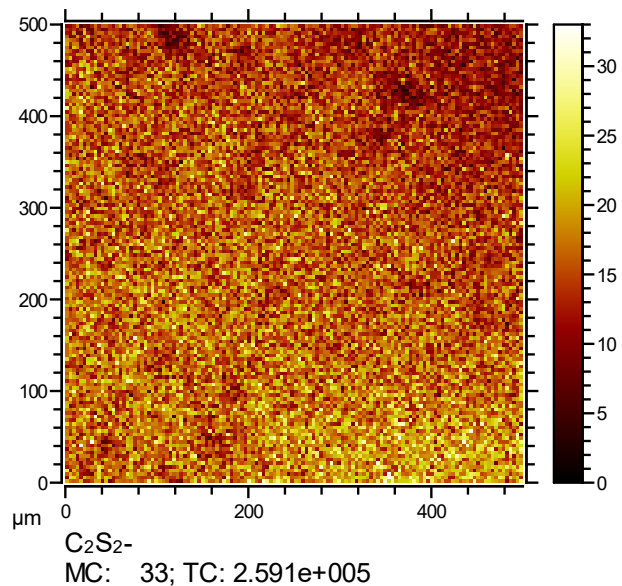

(d)

Figure 6. ToF-SIMS negative-ion images of $\mathrm{BX}$ absorbed marmatite surface at $\mathrm{pH}$ 6.5. (a): $\mathrm{C}_{4} \mathrm{H}_{9} \mathrm{OCS}_{2}{ }^{-}$; (b): $\mathrm{OCS}_{2} \mathrm{Zn}^{-} ;(\mathbf{c}): \mathrm{OCS}_{2} \mathrm{Fe}^{-} ;(\mathbf{d}): \mathrm{C}_{2} \mathrm{~S}_{2}{ }^{-}$.

Figure 7 shows the ToF-SIMS negative-ion images of Cu-activated marmatite surface after interaction with xanthate at $\mathrm{pH}$ 6.5. In the $500 \times 500 \mu \mathrm{m}^{2}$ analysis area, the $\mathrm{C}_{4} \mathrm{H}_{9} \mathrm{OCS}_{2}{ }^{-}$fragment ion derived from xanthate has an incompletely uniform distribution. However, contrary to the results shown in Figure 3, $\mathrm{C}_{4} \mathrm{H}_{9} \mathrm{OCS}_{2}{ }^{-}, \mathrm{OCS}_{2} \mathrm{Fe}^{-}, \mathrm{OCS}_{2} \mathrm{Cu}^{-}, \mathrm{OCS}_{2} \mathrm{Zn}^{-}, \mathrm{CuS}_{2}^{-}$, and $\mathrm{C}_{2} \mathrm{~S}_{2}^{-}$have similar spatial distributions. This indicates that after $\mathrm{Cu}$ activation of marmatite, different types of xanthate adsorbent on the surface have similar distributions. 


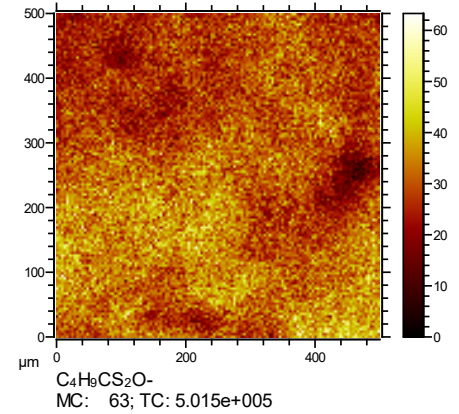

(a)

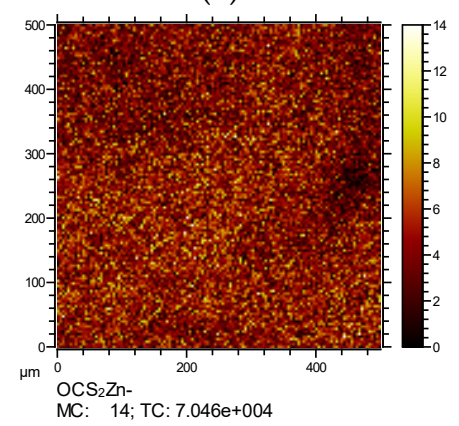

(d)

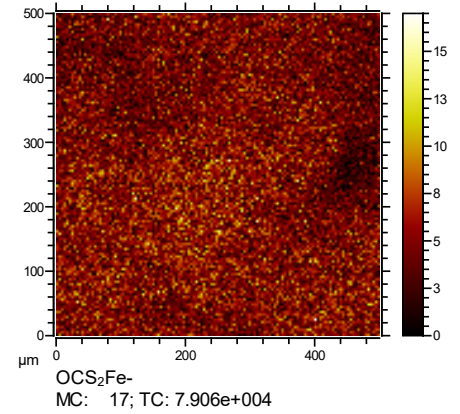

(b)

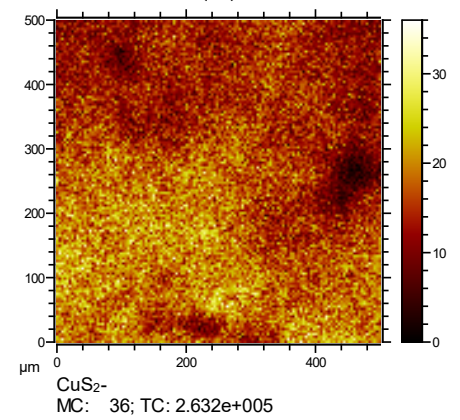

(e)

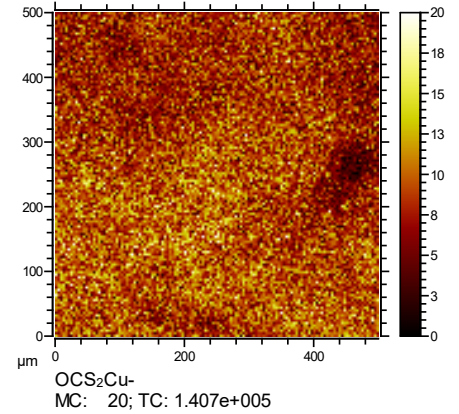

(c)

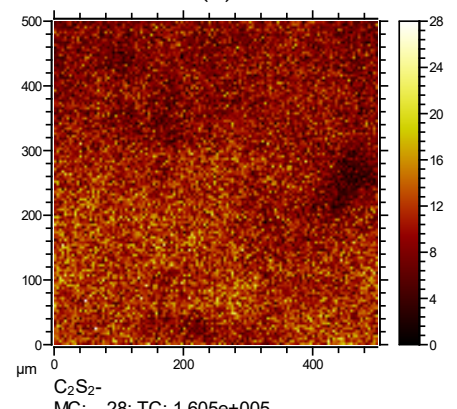

(f)

Figure 7. ToF-SIMS negative-ion images of $\mathrm{Cu}$-activated marmatite surface after interaction with $\mathrm{BX}$ at $\mathrm{pH}$ 6.5. (a): $\mathrm{C}_{4} \mathrm{H}_{9} \mathrm{CS}_{2} \mathrm{O}^{-}$; (b): $\mathrm{OCS}_{2} \mathrm{Fe}^{-}$; (c): $\mathrm{OCS}_{2} \mathrm{Cu}^{-}$; (d): $\mathrm{OCS}_{2} \mathrm{Zn}^{-} ;(\mathbf{e}): \mathrm{CuS}_{2}{ }^{-} ;(\mathbf{f}): \mathrm{C}_{2} \mathrm{~S}_{2}{ }^{-}$.

\section{Conclusions}

In this work, the active sites and species involved in xanthate adsorption on sphalerite/marmatite surfaces were studied using adsorption capacity measurements, single mineral flotation, and ToF-SIMS analysis. The effects of Fe concentration on the xanthate adsorption capacity, $\mathrm{Cu}$ activation, and flotation response of sphalerite were determined. The following conclusions can be drawn.

(1) At $\mathrm{pH} 6.5$ without addition of copper sulfate, the xanthate adsorption capacity on the sphalerite was five times that for marmatite. After $\mathrm{Cu}$ activation, the amount of xanthate adsorbed on sphalerite was 2.5 times that for marmatite. The effect of $\mathrm{Cu}$ activation on the xanthate adsorption capacity of marmatite was greater than that for sphalerite.

(2) Xanthate reacted with $\mathrm{Zn}, \mathrm{Fe}$, and $\mathrm{Cu}$ to generate the corresponding metal xanthates. A major discovery was that xanthate can interact with $\mathrm{Fe}$ atoms in the crystal of sphalerite/marmatite, as well as with $\mathrm{Zn}$ and $\mathrm{Cu}$ on the surface. For $\mathrm{Cu}$-activated sphalerite/marmatite, there were fragment ions $\left(\mathrm{C}_{4} \mathrm{H}_{9}{ }^{+}, \mathrm{C}_{4} \mathrm{H}_{9} \mathrm{O}^{-}\right.$, and $\left.\mathrm{C}_{4} \mathrm{H}_{9} \mathrm{OCS}_{2}{ }^{-}\right)$from xanthate, and fragment ions $\left(\mathrm{CSCu}^{+}\right.$, $\mathrm{OCSCu}^{+}$, and $\mathrm{OCS}_{2} \mathrm{Cu}^{+}$) from copper xanthate. We detected $\mathrm{C}_{2} \mathrm{~S}_{2}{ }^{-}$fragment ions from dixanthogen, and dixanthogen may have been adsorbed on the surface of marmatite.

(3) After $\mathrm{Cu}$ activation, xanthate preferentially interacted with surface $\mathrm{Cu}$, which is more potent than Fe in the crystal of sphalerite/marmatite. The interaction between xanthate and Fe is weaker than that between xanthate and $\mathrm{Zn}$ or $\mathrm{Cu}$. This makes xanthate adsorption on the marmatite surface more difficult than sphalerite surface. The amounts of $\mathrm{Cu}$ and copper xanthate adsorbed on the marmatite surface were lower than those on the sphalerite surface, because Fe occupies $\mathrm{Cu}$ and $\mathrm{Zn}$ exchange sites.

These results help to address the long-standing controversy regarding the products and mechanisms of xanthate adsorption on Fe-bearing sphalerite surfaces.

Author Contributions: Conceptualization, H.L., J.D., and S.L.; data curation, H.L. and W.C.; formal analysis, H.L., J.D., W.C., S.L., and L.H.; funding acquisition, J.D.; investigation, J.D. and S.L.; methodology, H.L. and L.H.; project administration, J.D.; resources, W.C.; validation, H.L. and J.D.; writing-original draft, H.L., J.D., and S.L.; writing-review and editing, J.D.; G.F., and H.X. 
Funding: This research was funded by National Natural Science Foundation of China (51764022 \& 51404119), Fok Ying Tong Education Foundation (161046), China Postdoctoral Science Foundation (2018M632810), and Open Project of State Key Laboratory of Mineral Processing Science and Technology (BGRIMM-KJSKL-2017-15), and Open Project of Key Laboratory of Biohydrometallurgy, Ministry of Education, Central South University (MOEKLB1706).

Acknowledgments: The authors would like to acknowledge the National Natural Science Foundation of China, Fok Ying Tung Education Foundation, and China Postdoctoral Science Foundation. Last but not least, the authors would like to thank the Zhengzhou University, Kunming University of Science and Technology, Beijing General Research Institute of Mining \& Metallurgy, and Central South University in providing the research facilities to execute this research. We sincerely thank Helen McPherson, from Liwen Bianji, Edanz Editing (www.liwenbianji. $\mathrm{cn} / \mathrm{ac})$, for editing the English text of a draft of this manuscript.

Conflicts of Interest: The authors declare no conflict of interest.

\section{References}

1. Fontboté, L.; Kouzmanov, K.; Chiaradia, M.; Pokrovski, G.S. Sulfide minerals in hydrothermal deposits. Elements 2017, 13, 97-103. [CrossRef]

2. Deng, J.-S.; Mao, Y.-B.; Wen, S.-M.; Liu, J.; Xian, Y.-J.; Feng, Q.-C. New influence factor inducing difficulty in selective flotation separation of $\mathrm{Cu}-\mathrm{Zn}$ mixed sulfide minerals. Int. J. Miner. Metall. Mater. 2015, 2, 111-115. [CrossRef]

3. Thella, J.; Farrokhpay, S.; Nguyen, A.V. The influence of water quality on sulfide mineral flotation-a review. In Proceedings of the Asia Pacific Confederation of Chemical Engineering Congress 2015: APCChE 2015, Incorporating CHEMECA 2015, Melbourne, Australia, 27 September-1 October 2015; Engineers Australia: Barton, Australia, 2015; pp. 2405-2408.

4. Nemchinova, L.; Zimin, A. Thermomechanical aspect of selective flotation of sphalerite and pyrite. Eurasian Min. 2015, 1, 19.

5. Deng, J.; Lei, Y.; Wen, S.; Chen, Z. Modeling interactions between ethyl xanthate and Cu/Fe ions using DFT/B3LYP approach. Int. J. Miner. Process. 2015, 140, 43-49. [CrossRef]

6. Liu, J.; Wen, S.; Wang, Y.; Deng, J.; Chen, X. Transition state search study on the migration of Cu absorbed on the $\mathrm{S}$ sites of sphalerite (110) surface. Int. J. Miner. Process. 2016, 147, 28-30. [CrossRef]

7. Sarvaramini, A.; Larachi, F; Hart, B. Collector attachment to lead-activated sphalerite-Experiments and DFT study on pH and solvent effects. Appl. Surf. Sci. 2016, 367, 459-472. [CrossRef]

8. Deng, J.; Wen, S.; Xian, Y.; Liu, J.; Bai, S. New discovery of unavoidable ions source in chalcopyrite flotation pulp: Fluid inclusions. Miner. Eng. 2013, 42, 22-28. [CrossRef]

9. Deng, J.; Wen, S.; Liu, J.; Xian, Y.; Wu, D.; Bai, S. New source of unavoidable ions in bornite flotation aqueous solution: Fluid inclusions. Ind. Eng. Chem. Res. 2013, 52, 4895-4901. [CrossRef]

10. Deng, J.-S.; Wen, S.-M.; Wu, D.-D.; Liu, J.; Zhang, X.-L.; Shen, H.-Y. Existence and release of fluid inclusions in bornite and its associated quartz and calcite. Int. J. Miner. Metall. Mater. 2013, 20, 815-822. [CrossRef]

11. Mohseni, M.; Abdollahi, M.; Poursalehi, R.; Khalesi, M.R. An insight into effect of surface functional groups on reactivity of Sphalerite (110) surface with Xanthate collector: A DFT study. J. Min. Environ. 2017, 9, 431-439.

12. Long, X.; Chen, Y.; Chen, J.; Xu, Z.; Liu, Q.; Du, Z. The effect of water molecules on the thiol collector interaction on the galena $(\mathrm{PbS})$ and sphalerite $(\mathrm{ZnS})$ surfaces: A DFT study. Appl. Surf. Sci. 2016, 389, 103-111. [CrossRef]

13. Liu, J.; Wang, Y.; Luo, D.; Chen, L.; Deng, J. Comparative study on the copper activation and xanthate adsorption on sphalerite and marmatite surfaces. Appl. Surf. Sci. 2018, 439, 263-271. [CrossRef]

14. Cook, N.J.; Ciobanu, C.L.; Pring, A.; Skinner, W.; Shimizu, M.; Danyushevsky, L.; Saini-Eidukat, B.; Melcher, F. Trace and minor elements in sphalerite: A LA-ICPMS study. Geochim. Cosmochim. Acta 2009, 73, 4761-4791. [CrossRef]

15. Pattrick, R.A.; Mosselmans, J.F.W.; Charnock, J.M. An X-ray absorption study of doped sphalerites. Eur. J. Mineral. 1998, 10, 239-250. [CrossRef]

16. Benedetto, F.D.; Andreozzi, G.; Bernadini, G.; Borgheresi, M.; Caneschi, A.; Cipciani, C.; Gatteschi, D.; Romanelli, M. Short range order of $\mathrm{Fe}^{2+}$ impurities, isolated and in pairs. ZnS and CdS studies by the Mossbauer effect. Phys. Chem. Miner. 2005, 32, 339-348. [CrossRef] 
17. Wright, K.; Gale, J.D. A first principles study of the distribution of iron in sphalerite. Geochim. Cosmochim. Acta 2010, 74, 3514-3520. [CrossRef]

18. Quast, K.; Hobart, G. Marmatite depression in galena flotation. Miner. Eng. 2006, 19, 860-869. [CrossRef]

19. Harmer, S.L.; Mierczynska-Vasilev, A.; Beattie, D.A.; Shapter, J.G. The effect of bulk iron concentration and heterogeneities on the copper activation of sphalerite. Miner. Eng. 2008, 21, 1005-1012. [CrossRef]

20. Lepetit, P.; Bente, K.; Doering, T.; Luckhaus, S. Crystal chemistry of Fe-containing sphalerites. Phys. Chem. Miner. 2003, 30, 185-191. [CrossRef]

21. Chen, Y.; Chen, J.; Guo, J. A DFT study on the effect of lattice impurities on the electronic structures and floatability of sphalerite. Miner. Eng. 2010, 23, 1120-1130. [CrossRef]

22. Szczypa, J.; Solecki, J.; Komosa, A. Effect of surface oxidation and iron contents on xanthate ions adsorption of synthetic sphalerites. Int. J. Miner. Process. 1980, 7, 151-157. [CrossRef]

23. Boulton, A.B. Improving Sulphide Mineral Flotation Selectivity Against Iron Sulphide Gangue. Ph.D. Thesis, University of South Australia, Adelaide, Australia, 2002.

24. Gigowski, B.; Vogg, A.; Wierer, K.; Dobias, B. Effect of Fe-lattice ions on adsorption, electrokinetic, calorimetric and flotation properties of sphalerite. Int. J. Miner. Process. 1991, 33, 103-120. [CrossRef]

25. Chandra, A.P.; Gerson, A.R. A review of the fundamental studies of the copper activation mechanisms for selective flotation of the sulfide minerals, sphalerite and pyrite. Adv. Colloid Interface Sci. 2009, 145, 97-110. [CrossRef] [PubMed]

26. Boulton, A.; Fornasiero, D.; Ralston, J. Effect of iron content in sphalerite on flotation. Miner. Eng. 2005, 18, 1120-1122. [CrossRef]

27. Yu, R.; Qiu, G.; Hu, Y.; Qin, W. Adsorption mechanism of ethyl xanthate on marmatite. Metal Mine 2004, 29-31. (In Chinese)

28. Zhang, Q.; Hu, Y.; Xu, J.; Chen, T. Study of the marmatite collectorless flotation. Nonferrous Met. Mieral Process. Sect. 2005, 19-21. (In Chinese)

29. Zhang, Q.; Yue-Hua, H.U.; Guo-Hua, G.U.; Jing, X.U. Mechanism of $\mathrm{Cu}^{2+}$ ion activation flotation of marmatite in absence and presence of ethyl xanthate. Chin. J. Nonferrous Met. 2004, 14, 676-680. (In Chinese)

30. Pattrick, R.A.D.; England, K.E.R.; Charnock, J.M.; Mosselmans, J.F.W. Copper activation of sphalerite and its reaction with xanthate in relation to flotation: An X-ray absorption spectroscopy (reflection extended X-ray absorption fine structure) investigation. Int. J. Miner. Process. 1999, 55, 247-265. [CrossRef]

31. Khmeleva, T.N.; Chapelet, J.K. Depression mechanisms of sodium bisulphite in the xanthate-induced flotation of copper activated sphalerite. Int. J. Miner. Process. 2006, 79, 61-75. [CrossRef]

32. Mikhlin, Y.; Karacharov, A.; Tomashevich, Y.; Shchukarev, A. Interaction of sphalerite with potassium n-butyl xanthate and copper sulfate solutions studied by XPS of fast-frozen samples and zeta-potential measurement. Vacuum 2016, 125, 98-105. [CrossRef]

33. Popov, S.R.; Vučinić, D.R. Floatability and adsorption of ethyl xanthate on copper-activated sphalerite in weakly acidic medium. Colloids Surf. 1990, 47, 81-94. [CrossRef]

34. Sodhi, R.N. Time-of-flight secondary ion mass spectrometry (TOF-SIMS):-Versatility in chemical and imaging surface analysis. Analyst 2004, 129, 483-487. [CrossRef] [PubMed]

35. Sutherland, K.L.; Wark, I.W. Principles of Flotation; Australasian Institute of Mining and Metallurgy: Carlton, Victoria, Australia, 1995.

36. Ejtemaei, M.; Nguyen, A.V. Characterisation of sphalerite and pyrite surfaces activated by copper sulphate. Miner. Eng. 2017, 100, 223-232. [CrossRef]

37. Gerson, A.R.; Lange, A.G.; Prince, K.E.; Smart, R.S.C. The mechanism of copper activation of sphalerite. Appl. Surf. Sci. 1999, 137, 207-223. [CrossRef]

38. Chen, J.; Chen, Y.; Zeng, X.; Li, Y. First principle study of effect of Fe impurity on electronic structure and activation of sphalerite surface. Chin. J. Nonferrous Met. 2009, 19, 1517-1523. (In Chinese)

(C) 2019 by the authors. Licensee MDPI, Basel, Switzerland. This article is an open access article distributed under the terms and conditions of the Creative Commons Attribution (CC BY) license (http://creativecommons.org/licenses/by/4.0/). 